\title{
E-ticarette Türkçenin özensiz kullanımı: A101 örneği
}

\section{Ahmet KAYASANDIK1}

\begin{abstract}
APA: Kayasandık, A. (2020). E-ticarette Türkçenin özensiz kullanımı: A101 örneği. RumeliDE Dil ve Edebiyat Araşturmaları Dergisi, (19), 162-176. DOI: 10.29000/rumelide.752230.
\end{abstract}

\section{$\ddot{\mathbf{O} z}$}

Dilin asıl işlevini doğru bir şekilde yerine getirebilmesi, onu kurallarına uygun biçimde kullanmaya bağlıdır. Son zamanlarda sezgiye dayalı anlaşmayla yetiniliyor. Konuya gereken duyarlılık gösterilmiyor. Bunun gibi çeşitli sebeplerle dil yanlışlarına yenileri ekleniyor. Bunlar da özellikle internet, televizyon, radyo, gazete, dergi, afiş, broşür, sosyal medya uygulamaları gibi araçlarla çok hızlı bir şekilde yayılıyor ve gittikçe kanıksanmaya başlıyor. İnternetten alışverişin yaygınlaşmaya başladığı günümüzde bu amaçla tasarlanan e-ticaret sitelerine de büyük sorumluluk düşüyor. Ağ sayfalarındaki dil yanlışları ve dilin özensiz kullanımı hem bu web sitelerini örnek alarak tasarlanan yenilerini hem de kullanıcıları olumsuz etkilemekte, yanlışların yayılmasına sebep olmaktadır. Dil yanlışlarının çoğunlukla çeşitli tasarımlarla ve kompozisyonlarla ürün ambalajlarına serpiştirilen bilgilerin ağ sayfasına aktarılmasında yapıldığı görüldü. Tamlama kurallarına, sıfatların sırasına, yazım ve noktalama gibi hususlara dikkat edilmediği tespit edildi. Dil yanlışlarının önemli bir kısmı, sıfat tamlamalarındaki tamlayanların yanlış sıralanmasından ve isim tamlamalarındaki iyelik ekinin eksikliğinden kaynaklanmaktadır. a101.com.tr ağ sayfasıyla sınırlı bu çalışmada tespit edilen olumsuzluklar; tamlama yanlışları, anlatım bozuklukları, yazım, noktalama ve kısaltma yanlışlıkları alt başlıklarıyla gruplandı ve düzeltme önerileri verildi. Sabit bilgilendirmeler ve kategori başlıkları bir uzmandan yardım alınarak bir defada kalıcı olarak düzeltilebilir. Ürün bilgileri, doğru yazımla ve doğru sırayla veri tabanına girilebilir. Üreticiler, ürün görsellerini ve ürüne ait bilgileri kendi a $\breve{g}$ sayfalarından çekilebilecek uygulamalar geliştirebilirler.

Anahtar kelimeler: Market Türkçesi, tamlama yanlışları, anlatım bozuklukları, yazım ve noktalama yanlışları

\section{Improper use of Turkish in e-commerce: A101 example}

\begin{abstract}
The language fulfills its original function when used properly. Recently, intuitive communication has been more widely used. It is seen that essential sensitivity is not shown to the subject. Language mistakes are gradually increasing for various reasons. These are spreading very fast, especially with tools such as internet, television, radio, newspaper, magazine, poster, brochure, and social media applications and are becoming more and more normal. Today, when online shopping has started to become widespread, e-commerce sites designed for this purpose have a great responsibility. Language mistakes and sloppy use of the web pages affect both new users and users designed by using these websites as an example, and spread the mistakes. It is seen that language mistakes are mostly made in transferring the information interspersed with product designs and compositions to the web page. It was determined that attention was not paid to completion rules, order of adjectives,
\end{abstract}

1 Öğr. Gör. Dr., Abdullah Gül Üniversitesi, Rektörlük Türk Dili Bölümü (Kayseri, Türkiye), kayasandik@gmail.com, ORCID ID: oooo-0001-8633-034X [Makale kaylt tarihi: 15.05.2020-kabul tarihi: 20.06.2020; DOI: 10.29000/rumelide.752230] 
spelling and punctuation. An important part of language mistakes arises from the misplacement of the phrases in adjective clauses and lack of possessive suffix in noun clauses. The completion errors, expression disorders, spelling, punctuation and abbreviation errors identified in this study limited to the a101.com.tr web page were grouped and correction suggestions were given. Fixed notices and category titles can be permanently corrected at once with the help of a specialist. Product information can be entered into the database with the correct spelling and in the correct order. Manufacturers can develop applications that can pull product images and product information from their web pages.

Keywords: Market Turkish, phrase mistakes, expression disorders, spelling and punctuation mistakes

\title{
Giriş
}

"İnsanlar arasında anlaşmayı sağlayan tabiî bir vasıta, kendisine mahsus kanunları olan ve ancak bu kanunlar çerçevesinde gelişen canlı bir varlık, temeli bilinmeyen zamanlarda atılmış bir gizli antlaşmalar sistemi, seslerden örülmüş içtimaî bir müessese" (Ergin, 1982: 4) olan dilin en önemli özelliği doğal bir anlaşma aracı olmasıdır. Dilin anlaşma işlevini doğru bir şekilde yerine getirmesi kendi kuralları çerçevesinde gerçekleşir.

Tarihî süreçte çok sayıda milletle ve kültürle alışverişte bulunan, ayrıca çok geniş bir coğrafyada uzun süredir varlı̆̆ını devam ettiren Türklerin konuştuğu bu büyük dilde yabancı dil unsurlarının bulunması doğaldır. Ancak

\begin{abstract}
"Batı kaynaklı yabancı dil unsurlarının Türk dilinde yerli yersiz, gerekli gereksiz kullanılması, tıpkı geçmişte doğu kaynaklı pek çok dil unsur ile birlikte onların kültür unsurlarını da dolaylı veya doğrudan getirerek Türk kültürüne katması, yamaması ve nihayet açıç̧a denilmelidir ki, kimi kez de belirli alanlarda onu bozmaya, olumsuz biçimde değiştirmeye, yozlaştırmaya götürmesi durumu, yarın için, bir daha ve bu kez de batı kaynaklı dil unsurları aracılığıyla olacaktır. Çünkü, Türkçede kirlenmeye yol açan batı kaynaklı dil unsurları, bazı kimselerce her geçen gün biraz daha keyfî şekilde, bilinçsizce, bilgisizce, onulmaz bir taklitçilik dürtüsü ve tedavisi mümkün olmayan bir kendine güvensizliğin doğurduğu yaptırımla veya daha başka sebepler sonucunda gittikçe artan oranda kullanılmaktadır" (Ersoylu, 2009:14).
\end{abstract}

Ders kitaplarında, televizyonlarda, gazetelerde, dergilerde, broşürlerde, internet sayfalarında, afişlerde ve özellikle diğer iletişim araçlarında dile gereken özen gösterilmediği sürece bu yanlışlar ve olumsuzluklar hızla yayılmakta ve gittikçe kanıksanmaktadır. İnternetten alışverişin yaygınlaşmaya başladığı günümüzde bu amaçla tasarlanan e-ticaret sitelerine de büyük sorumluluk düşüyor.

Bugün Türkçenin güncel ve önemli sorunlarından biri de "sezgiye dayalı anlaşma"yla yetinilip dile gereken özenin gösterilmemesidir. Muhatabın ne demek istediği sezgi yoluyla anlaşıldığından onun meramını anlatmak için seçtiği kelimelere, ifadenin dilin kurallarına uygun olup olmadığına bakılmıyor. Her türlü kitle iletişim aracıyla bu nitelikteki yanlışların hızla yayılması, tekrarında beis görülmemesi, Türkçenin geleceği adına kaygı verici boyutlara ulaşmıştır.

Pazarlamada yapılan Türkçe yanlışlarıyla ilgili olarak Görgülü (2008), aslında kurumsallaşmış büyük ölçekli ajansların veya 'butik' denilen tarzda işler yapan küçük ölçekli reklam ajanslarının hem grafik, hem de Türkçe konusunda titiz oldukları; esas sorunun asıl işi reklam yaratıcılığı olmadığı hâlde bu alana el atan 'üretici' şirketlerde ortaya çıktığı tespitini yapar. Matbaalarda yazılan metinlerin, dijital baskı merkezlerinde yapılan grafik tasarımların veya prodüksiyon şirketlerinde senaryosu yazılan 
reklam filmlerinin içerdikleri Türkçe yanlışlarıyla hem toplumsal değerlere hem de reklam verenin marka değerine ciddi zararlar verebileceği kanaatindedir. Görgülü (2008), bu olumsuzlukların ortaya çıkmasında Türkçe yanlışları konusunda 'ısrarlı' ve 'her şeyi çok iyi bilen' müşterilerin payı olduğunu da vurgular.

Hangi gerekçelerden/sebeplerden kaynaklanırsa kaynaklansın mevcut hâliyle bile ortada Türkçe bakımından ciddi bir sorun olduğu muhakkaktır. Sezgiye dayalı anlaşma yolu tercih edildiği ve konuya gereken duyarlılık gösterilmediği sürece yakın gelecekte bu çalışmada örneklenen dil yanlışlarına yenilerinin eklenmesi sürpriz olmayacaktır.

$\mathrm{Bu}$ çalışmada 9.000 mağazasıyla Türkiye'nin 81 ilinde ve her ilçesinde faaliyet gösteren ve A101 markasıyla bilinen Yeni Mağazacılık AŞ'nin a101.com.tr ağ sayfasındaki özensiz kullanımlar, dil yanlışları ve anlatım bozuklukları tespit edilmiştir. Veriler, adı geçen sayfadan 5-10 Mart 2020 tarihleri arasında derlenmiştir. Kelimeler arasında ve noktalama işaretinden sonra boşluk bırakılmadan yazılan örnekler, ağ sayfasındaki bu yanlışlı̆̆a da dikkat çekmek amacıyla özgün hâliyle korunmuştur:

\section{Tamlama yanlışları}

Ağ sayfasındaki dil yanlışlarının önemli bir kısmı, sıfat tamlamalarındaki tamlayanların yanlış sıralanmasından ve isim tamlamalarındaki iyelik ekinin eksikliğinden kaynaklanmaktadır. $\mathrm{Bu}$ yanlışlıkların çeşitli sebepleri şöyle sıralanabilir:

Öncelikle ağ sayfası ticari amaçlara en iyi şekilde hizmet edecek şekilde tasarlandığı için arama motorlarında daha fazla ürün ve seçenek sıralanabilsin diye algoritmalar tamlamalara göre değil kelimelere göre oluşturulmuştur. İyelik eki eksikliğinden kaynaklanan yanlışların bir kısmı, bu durumla izah edilebilir. Bazı ürünlerin ambalajlarındaki tamlama yanlışlarının ağ sayfasına aynen aktarılması, diğer bir sebeptir. Bazı örneklerde ise özensizlik sebebiyle ürün ambalajındaki doğru ifadelerin sayfaya eksik veya yanlış aktarılması söz konusudur.

Ürünün markası, serisi, niteliği, içeriği, bedeni, rengi, ebadı, ölçüsü gibi bilgiler, değişik tasarımlarla/kompozisyonlarla ürün ambalajında yer almaktadır. Bu bilgiler, ağ sayfasına aktarılırken tamlayanların sırası çoğu zaman gözetilmediği ve sıralananlar arasına ayırıcı noktalama işareti konmadığı için çok ciddi yanlışlar ortaya çıkmaktadır. Yanlış olsa bile, aynı nitelikteki ürünlerin yazılışları arasındaki tutarsızlıklar, özensizliğin sonucu olarak değerlendirilebilir.

\section{1. İsim tamlaması yanlışlıkları}

Temelde iyelik eki eksikliğinden kaynaklanan isim tamlaması yanlışlıkları, ă̆ sayfasında değişik şekillerde tespit edilmiştir:

a) İyelik eki eksikliğinden kaynaklanan yanlışlar: Bir kelime grubunun isim tamlaması olabilmesi için tamlanan isme, iyelik eki mutlaka getirilmelidir. Aşağıda sıralanan örneklerin eksiz isim tamlaması olarak izahı doğru olmayacaktır. Çünkü "Pratik olarak eksiz ad tamlaması ile sıfat tamlaması şu şekilde ayırt edilebilir: Tamlamanın sıfat tamlaması olabilmesi için tamlayanın tamlananı benzerlik, nitelik yönünden belirtmesi; ad tamlaması olması için de tamlayanın tamlananı ilgi ve sahiplik yönünden belirtmesi gerekmektedir" (Tokyürek, Pekacar, 2014: 33). 
Köşeli parantez içindeki iyelik ekinin yazılmadığı şu isim tamlamaları bunun örneklerindendir: $E v$

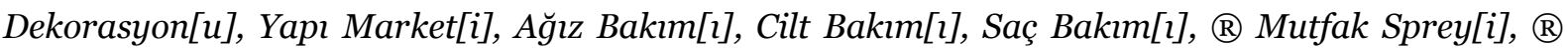

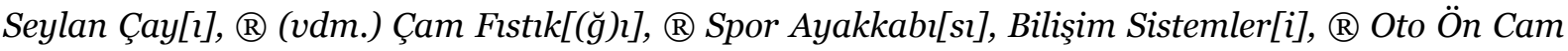

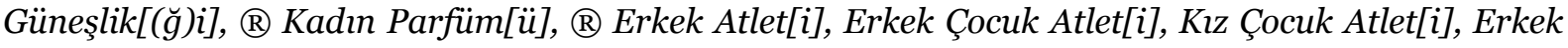

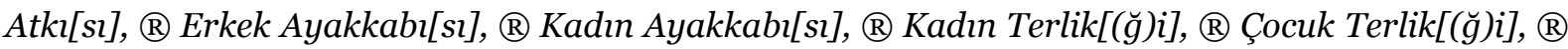

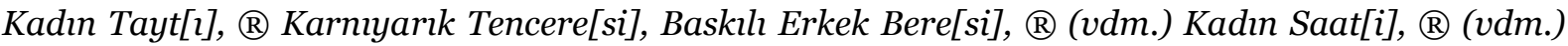
Erkek Saat[i], ® Erkek Cüzdan[2], ® Kadın Deodorant[1], ® Besleyici Kür Şampuan[1], Kadın

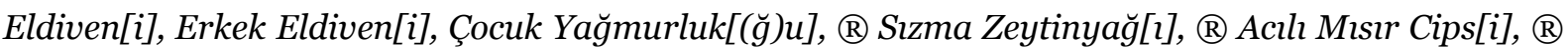
Demlik Poşet[i], ® Cep Telefon[u] Uyumlu Lens, Hobi Raket Set[i], Ahşap Kepçe Kaşık Set[i], Çocuk Puf Yelek [puf çocuk yeleği], hamile giyim[i],cep telefon[u], bebek telsizler[i].

b) Ürün ambalajında doğru yazıldığı hâlde ağ sayfasına yanlış aktarılanlar: Sıralanan örneklerde yay ayraç içindekiler ürün ambalajındaki doğru ifadeyi göstermektedir: (® Antep Fıstığı) ® Antep Fıstık, (Andersen Masalları) Andersen Masallar.

c) Ürün ambalajında doğru yazıldığı hâlde ağ sayfasına aktarılırken tamlayanla tamlananın yer değiştirilmesiyle Türkçedeki herhangi bir kelime grubuna dâhil edilemeyecek şekle dönüştürülenler: (Diğer markalarda ve çeşitlerde aynı yanlışın bulunduğu örneklerin hepsi yazılmamıştır) (® Salatahk Turşusu) ® Turşu Salatalık, (® Domates Salçası) ® Salça Domates, (® Karabuğdaylı Glutensiz Un)

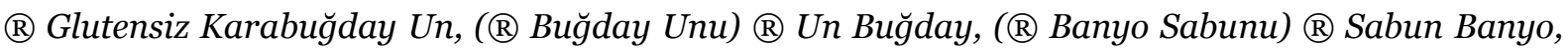
(® Kavala Kurabiyesi) $₫$ Kurabiye Kavala, $(\circledR$ Elma Sirkesi) $₫$ Sirke Elma Anal, $(\circledR$ Acr Biber Salçası) ® Salça Biber Acı, (® Oda Kokusu BAHAR TAZELİĞİ) Oda Kumaş Spr.bahar Tazeliği 400

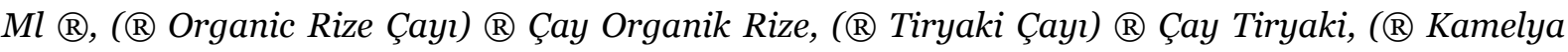

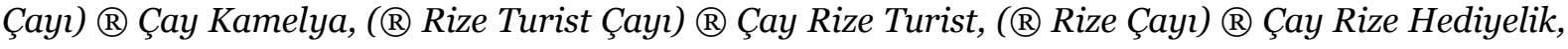

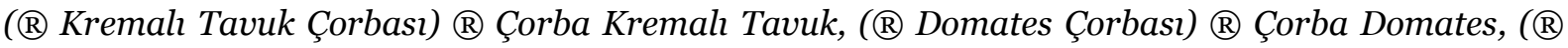

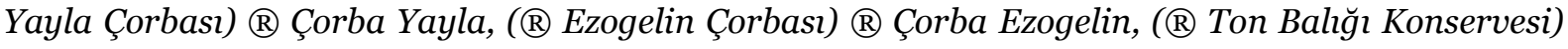
(R) Konserve Balk Ton.

Ürün ambalajındaki İngilizce ve Türkçe ibareler, şu örneklerde ağ sayfasında farklı yorumlanabilecek şekilde yazılmıştır: (® organic Hemşin Tea) @ Çay Organik Hemşin, ( $($ Adult Dog Food Kuzu Etli) ® Kuzulu Yetişkin Köpek Mama 15 Kg, (® Adult Cat Food Tavuk Etli) ${ }^{\circledR}$ Tavuklu Yetişkin Kedi Mama $15 \mathrm{Kg}$

ç) Ürün bilgilerinin yanlış sırayla ağ sayfasına aktarılmasından kaynaklananlar: Bu gruptaki yanlışların çoğu, ürün ambalajındaki ibarelerin yanlış sıralamayla, aralarına ayırıcı herhangi bir noktalama işareti konmadan ağ sayfasına aktarılmasından kaynaklanmaktadır. Ürün ambalajlarında daha belirgin ve farklı tasarımlarla veya fontlarla marka adı (®), ürün (salça) ve çeşidi (domates) gibi bilgiler bulunmaktadır. Bu bilgiler tamlama kuralları ve noktalama işaretleri dikkate alınmadan ă sayfasına aktarıldığında dil yanlışları ortaya çıkmaktadır: $₫$ Sirke Üzüm [@ üzüm sirkesi], $₫$ Sirke Elma [ ${ }^{\circledR}$ elma sirkesi], $®$ Salça Domates [ ${ }^{\circledR}$ domates salçası], ${ }^{\circledR}$ Turşu Salatahk [ ${ }^{\circledR}$ salatahk

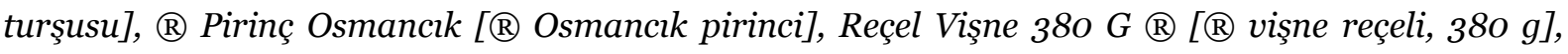
Reçel Böğürtlen $380 \mathrm{G}$ ® [® böğürtlen reçeli, 38o g], ® Zeytinyă̆ı Sızma [® sızma zeytinyă̆ı].

d) Hem sıralama yanlışı hem iyelik eki eksikliği bulunanlar: Erkek \%10o Deri Kemer [\% 100 deri erkek kemeri], @ Kedi Mama \& Su Kabı $250 x 2 \mathrm{Ml}$ - Yeşil [® yeşil kedi maması ve su kabı, 250x2 ml], ${ }^{\circledR}$ For Men Intense Edt $75 \mathrm{ml}+$ Deodorant Stick $75 \mathrm{gr}$ Erkek [ ${ }^{\circledR}$ for men intense EDT, $75 \mathrm{ml}$ ve stick erkek deodorantı, 75 g], @ Güneşlikli Bebek Şişme Havuz [® güneşlikli, şişirme bebek havuzu], @ 
Deodorant Kadın [® kadın deodorantı] @ Erkek Kısa Kol Pijama [® kısa kollu erkek pijaması], @

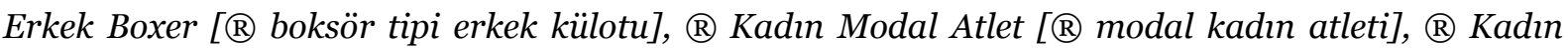

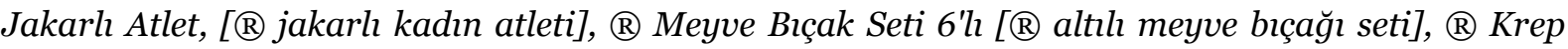
Tava $22 \mathrm{Cm}$ - Siyah [® siyah krep tavasl, $22 \mathrm{~cm}$ ], Kadın Bere - Bej Rengi [bej rengi kadın beresi], @

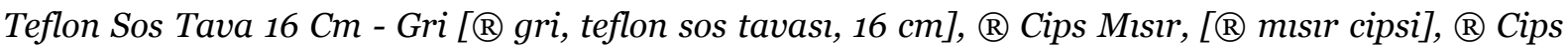

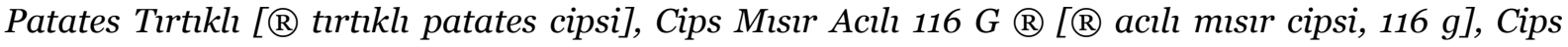

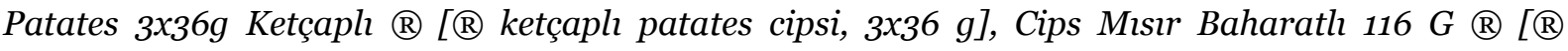
baharatlı mısır cipsi, 116 g], @ Çay Demlik Posset Karadeniz [® Karadeniz çayı, demlik poşeti], @ Bardak Poşet Çay [ ${ }^{\circledR}$ çay, bardak poşeti], ® Salça Domates Cam [ $₫$ domates salçası, cam kavanoz], ® Salça Domates Teneke, [® domates salçası, teneke kutu], $®$ Turşu Kornişon Az Tuzlu [® az tuzlu kornişon turşusu], @ Turşu Salatahk Alman Tipi [ ${ }^{\circledR}$ Alman tipi salatahk turşusu], ${ }^{\circledR}$ Salça Biber Tath [® tatlı biber salçası], Lisansh Çocuk Uzun Ko, Kırmızı [lisansh, uzun kollu, kırmızı, çocuk pijaması], Erkek Uzun Kollu Pijama [uzun kollu erkek pijaması], Erkek Askıl Çanta - Siyah [siyah, askılı erkek çantası], ® Erkek Eşofman Üst [® erkek eşofmanı üstü], @ Kadın Çorap Motifli [® motifli kadın çorabı], Bayan Simli Spor Ayakkabı [simli, bayan spor ayakkkabısı], @ Kadın Fleur Du Soir Parfüm [ ${ }^{\circledR}$ Fleur Du Soir kadın parfümü, ${ }^{\circledR}$ Deodorant Erkek Dark Temptation [ ${ }^{\circledR}$ Dark Temptation erkek deodorantı], ® Deodorant Pudrasız Kadın [® pudrasız kadın deodorantı], ${ }^{\circledR}$ Oda Spreyi Otomatik Yedek [® otomatik oda spreyi yedeği].

Motorlu Taşıt Ürünleri, Tiraş Ürünleri, Güneş Ürünleri gibi örneklerde ise yapı bakımından yanlışlık olmasa bile tamlanan kelimenin anlamında aykırllk söz konusudur.

\subsection{Sıfat tamlaması yanlışlıkları}

Bir kelimenin yalnız başına sıfat görevinde bulunması mümkün olmadığından aslında sıfat terimiyle kastedilen, sıfat tamlamasıdır. Sıfat tamlaması oluşturulurken tamlayan görevindeki unsur çekim eki almaz. "Bir sıfat tamlamasında, adı niteleyen aynı türde birden fazla sıfat ögesi bulunabilir. Tamlayan veya tamlanan, bir söz veya söz öbeği olabilir. Bu tür tamlamalarda vurgulanmak istenen öge, ada en yakın olan sıfattır" (Karaağaç, 2016: 495). Bir varlığın sadece bir niteliği olmadığından bir isim birden fazla sıfat tarafından nitelenebilir veya belirtilebilir. Bu durumda niteleme ve belirtme sıfatlarının dile uygun biçimde sıralanması gerekmektedir. İsim tamlamalarında olduğu gibi sıfat tamlaması yanlışlarını da iki grupta değerlendirmek uygun olacaktır:

a) Ürün kapağında/ambalajında doğru yazıldığı hâlde ağ sayfasında kelimelerin sırası değiştirilmek, eksik/fazla yazılmak suretiyle yanlış yazılanlar: Aşağıdaki örneklerde önce ürün ambalajında/kapağında doğru yazılanlar yay ayraç içinde verilmiş sonra ă̆ sayfasındaki şekli gösterilmiştir:

(® Sütlü Çikolata Kaplamah Kraker) ${ }^{\circledR}$ Kraker Sütlü Çik., $\left(\circledR\right.$ Bahlk Kraker) ${ }^{\circledR}$ Kraker Bahk, $(\circledR$ Bebe Sütlü Bisküvi) ${ }^{\circledR}$ Bebe Bisküvisi, ( ${ }^{\circledR}$ Karamel Waffle) ${ }^{\circledR}$ Gofret Karamelli Waffle, $\left({ }^{\circledR}\right.$ Çubuk Kraker) ® Kraker Çubuk, (® Çubuk Kraker, Peynirli) ® Kraker Çubuk Peynirli, (® Çikolatah Gofret) $₫$ Gofret Çikolatah, $(\circledR$ Peynirli Kraker) $₫$ Kraker Peynirli, ( $₫$ Pötibör Bisküvi) $₫$ Bisküvi

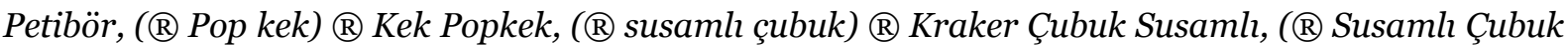
Kraker) ${ }^{\circledR}$ Kraker Susaml Çubuk, ( ${ }^{\circledR}$ Gala Çikolata Kaplamah Orman Meyveli Kek) ${ }^{\circledR}$ Orman Meyveli Kek Gala, (® Finger Bisküvi) $₫$ Bisküvi Finger, ( 99 Kat Tat) 9 Kat $₫$ Gofret Findık Kremah, (® Tüm Yüzeyler Çiçek Ferahlı̆̆ı) @ Tüm Yüzeyler Temizleyici Çiçek Ferahlı̆ı, (® Desenli Temizlik Bezi) @ Temizlik Bezi Desenli, (® Microfiber Temizlik Bezi) ${ }^{\circledR}$ Temizlik Bezi Microfiber, $(\circledR$ 
Makine Temizleyici Tablet) @ Bulaşık Makinası Tablet Temizleyici, (® Monarch Gold) $₫$ Monarch Kahve Gold Kavanoz, (® Burcum Yeşil Çay) $₫$ Çay Yeşil Burcum, (® Nane Limonlu Yeşil Çay) $₫$

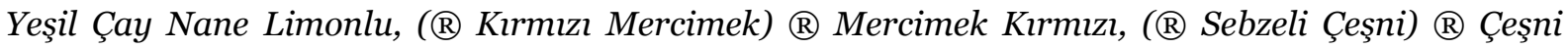
Sebzeli, (Portakal Aromah Gazh İçecek) ${ }^{\circledR}$ Gazh İçecek Gazoz Portakal, ( ${ }^{\circledR}$ Muzlu) ${ }^{\circledR}$ Bisküvi Muzlu

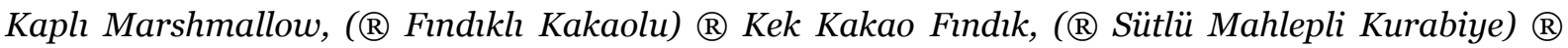

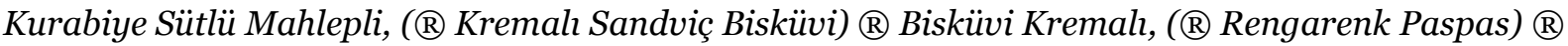

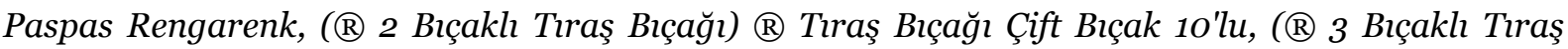

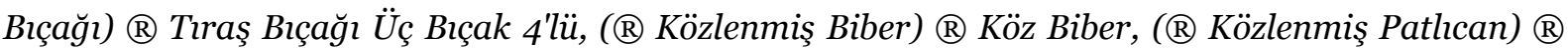
Köz Patlıcan, (® Beyaz Findıklı Çikolata) $₫$ Çikolata Findıklı Beyaz, (® günlük ped) ${ }^{\circledR}$ Hijyenik Ped Günlük Normal 4o'll.

b) Ürün bilgilerinin sıra gözetilmeden ağ sayfasına aktarılmasından kaynaklananlar: Bir isim birden fazla sıfat tarafından nitelendiğine/belirtildiğinde bunların hangi sırada olması gerektiğine dair yapılan araştırmalarda bazı ortak kabuller olsa bile sıralama sınırlılıklarının değişmez bir sırada verilmesinin zorluğu ifade edilmektedir. Özezen (2006) bu konuya dair çalışmasında Türkiye Türkçesi genel yazı dilinde niteleyenlerin ve belirtenlerin içerikleri bakımından belli bir sıraya göre dizildikleri yönünde kesin bir yargıya varamadığını ifade eder. Türkçede sınıflayıcı sıfatların betimleyici sıfatlardan sonra gelmesi ilkesinin geçerli olduğunu ifade eden Akşehirli (2015), Scott'ın önerdiği şu sifat dizilim modelini alıntılar: "sıra sayı > asıl sayı > özne yorumu > kanıtsal > boyut > uzunluk > ağırlık $>$ hız $>$ derinlik $>$ genişlik $>\imath s \imath>\imath$ slaklık/kuruluk $>$ yas, $>$ bic, im $>$ renk $>$ milliyet /köken $>$ malzeme" Özünlü (1978) de Türkçe için "Yas, > ölçü > biçim > nitelik > renk > yer > ad, Eski büyük uzun çirkin yeşil alt geçit" şeklinde bir dizilimden söz eder.

Yukarıda açıklandığı üzere değişik tasarımlarla/kompozisyonlarla ürün ambalajında/kapağında bulunan ürün bilgileri ağ sayfasına aktarılırken sıfatların sırası gözetilmeyince ve sıralananlar arasına ayırıcı noktalama işareti konmayınca büyük ve önemli yanlışlar ortaya çıkmaktadır. Ürünün uzunluğu, ağırlığı, litresi, bedeni, adedi ve rengi gibi nicelik veya nitelik bildiren ifadeler, doğru siralanmak kaydıyla (nicelik bildirenler yay ayraç içinde yazılmak) veya bunlar virgül ya da kısa çizgi işaretiyle ayrılmak suretiyle bu türdeki yanlışların çoğu düzeltilebilir. İsim tamlamasından sonra yazılan sıfatlar da tamlamanın önüne alınmalıdır.

® Bisküvi Çikolata Kremah, @ Sert Şeker Nane Aromal, @ Kek Meyveli, @ Draje Çikolata Kaph

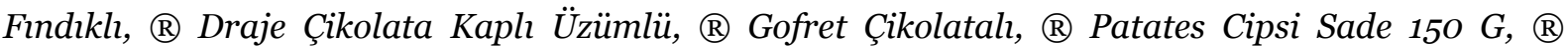
Çikolata Fındıklı 250 G, ® Zencefil Sert Şeker Bitk. 5 G, ® Çikolata Sütlü, ® Draje Çeşitleri Karışık,

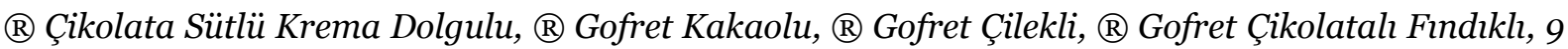
Kat ${ }^{\circledR}$ Gofret Çilek Kremah, @ Sakız Şekersiz Bublefresh, @ Çikolata Uzun Sütlü, ${ }^{\circledR}$ Renkli Toz Deterjan, @ Peçete Desenli, ® Yüzey Temizleyici Silikonlu, @ Toz Deterjan $8 \mathrm{Kg}$-Renkli, ${ }^{\circledR}$ Türkiye Serisi Amasya Elması Bulaşık Deterjanı 1350 Gr, ® Türkiye Serisi Adana Portakalı Bulaşık Deterjan $1350 \mathrm{ml}$, ® Toz Deterjan Beyaz 70oo Gr, ® Renkli Toz Deterjan $7 \mathrm{Kg}$, ® Toz Deterjan Beyaz 4 Kg, ® Toz Deterjan Renkli 4 Kg, (vdm.) @ Bulaşık Deterjanı Sivı, @ Yumuşatıcı Konsantre Gül, @ Mutfak Yağ Çözücü Sprey Limon, @ Renkli Sıvı Deterjan, @ Yumuşatıcı Konsantre Hanımeli, ( Oda Spreyi Otomatik Spring Fresh, @ Gül Yumuşatıcı, @ Loft Genel Temizlik Stvı, @ Yumuşatıcı Konsantre Taze Gül, ® Gül Yumuşatıcı Kon Karma, ® Renkli Toz Deterjan, ® Temizlik Seti 3'lü, ® Damlahk Katlamasız, @ Sütlü Osmanl Dibek Kahvesi, @ Hazır Tek İçimlik Türk Kahvesi, ${ }^{\circledR}$ Enerji İ̧eceği Şekersiz, ® Şalgam Suyu Acılı (vdm.), ® Türk Kahvesi Damla Sakızl Teneke, ® Dibek Türk

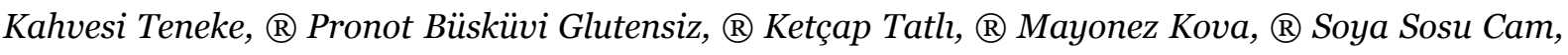

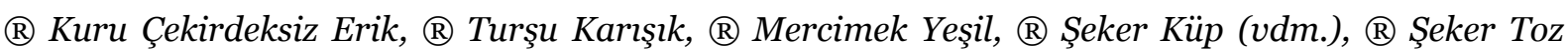


(vdm.), ® Şeker Esmer Küp, ® Pirinç Baldo, ® Nohut Koçbaşı, ® Bulgur Pilavlık, ® Bulgur Köftelik,

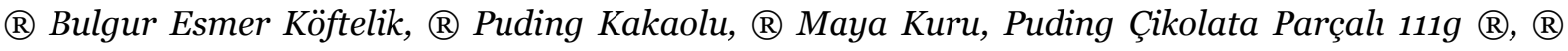
Pilavlık Pirinç Yerli, Toz Tath Tavukgöğsü 15og ®,® Pirinç Kırık, ® Süt Yağlı (vdm.), ® Süt Yartm Yağh (vdm.), ® Süt Kakaolu, ® Süt Çilekli, ® Misır Gevreği Çikolatal,, ® Süt Muzlu (vdm.), ® Yeşil Zeytin Çizik, ${ }^{\circledR}$ Yeşil Zeytin Biberli, ${ }^{\circledR}$ Yeşil Zeytin Krrma, ${ }^{\circledR}$ Yazhlk Helva Bademli, ${ }^{\circledR}$ Buğday ve Pirinç Gevreği Karışık Meyveli, @ Ekstra Güçlü Lavanta Büzgülü Orta Boy Torba, Helva Sade 175 G

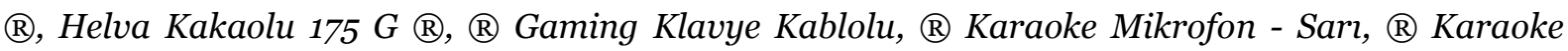
Mikrofon - Pembe, ${ }^{\circledR}$ Karaoke Mikrofon - Siyah, @ Elastik Tripod - Siyah, ${ }^{\circledR}$ Saç Kesme Makinesi Kırmızı), ® Yă̆ Ölçerli Baskül - Siyah, ® Su Isttıcı - Mor, ® 64 GB Cep Telefonu - Siyah (Diğer ürünlerin marka ve modellerinde de benzer kullanım), ® Selfie Çubuğu - Kırmızı, ® Bluetooth Hoparlör Suya Dayamıl, @ Ultra Micro SDHC Kart 16 GB, @ 16 Gb Ultra Micro Sdhc Kart, @ Çay Kaşığı Desenli, @ Asılabilir Duşakabin Rafi 2 Katl, @ Yuvarlak Saklama Kabı 3'lü, ® Mısır Kutusu Desenli Ve Lisanslı, Saklama Kabı Süzgeçli - Gri, ® Saklama Kabı 3 Lü Contasız Desenli Tekli, Kapaklı Kare Sığ Kase, @ Termal Uzun Alt İçlik, Saklama Kabı 4'lü - Dikdörtgen, Emaye Kek Kalıbı Siyah - Düz, @ Deniz Yatağ Dondurma, @ Can Simidi - Meyve Figürlü Ananas, Plastik Tabak 1o'lu, Ahşap Tepsi Desenli, Ahşap Tepsi Desen 2'li, Teflon Turta Kabı Mor, ${ }^{\circledR}$ Biftekli Ve Kümes Hayvanh 2.6 kg Yetişkin Köpek Maması, @ Kedi Maması Biftek/havuç [® biftekli ve havuçlu kedi maması], @ Sığır Etli Yetişkin Kuru Kedi Maması, Oto Deri Boyun Yastığı 2'li, @ Şampuan Istrgan Otlu 75o Ml, Hijyenik Ped Ultra Normal $₫$, ® Pudra Furçası Mor, ® Saf Kömür Özlü Siyah Kağıt Yüz Maskesi, ® Tiraş Jeli 200 ml Nemlendirici, @ Şampuan Orkide Özlü, @ Hassas Serinlik Cilt Tiraş Jeli 200 ml, @ Sivı Sabun Zeytinyağlı, ® Dudak 201 Kalemi, ® Sabun Zeytinyağhl, ® Tiraş Bıçağı Banyo 6'lı, @ Tiraş Bıçağı Yedek 2'li, Plastik Çocuk Klozet Kapağı, ® Porselen Düz Tabak 19 Cm, ® Mum Renkli 3o'lu, Kupa Rafi 7 Bölmeli, Emaye Kek Kalıbı Bordo, ® Termal Uzun Kol[lu] Üst İçlik - Mat Siyah SM, 120 Yaprak Sert Kapak Defter Çizgili 17x24, @ Desenli Matara Vida Kapak 750 Cc, Kaymaz Taban Saç[aklı] Yolluk Mavi $80 x 150$ cm, Makyaj Organizeri Büyük Arttırllabilir Çekmece[li], @ Ketçap Acr[ll]

En Çok Satanlar [Satılanlar], @ [Fesleğenli] Kurutulmuş Domates Ve Fesleğenli 107 G, @ Kadın Desenli Kaph Sü̈yen [ [ Kaph, desenli sütyen], ® Diş Macunu Anti-çürük [® çürümeyi önleyici diş macunu]

Kitaplara ait bilgiler, ağ sayfasına aktarılırken tutarlı bir sıra gözetilmediği gibi noktalama işaretlerinin kullanılmasında da birlik yoktur: (Aşağıdaki örneklerde yay ayraç içinde yazılanlar kitap görselindeki şeklidir.)

(İlk Bilgilerim Sebze Kartları) Sebze Bak Öğren Kartları - İlk Bilgilerim o-3 Yaş, (İlk Bilgilerim Renk ve Şekil Kartları) - Renk ve Şekil Bak Öğren Kartları, Nutuk - Mustafa Kemal Atatürk, (Hedef 2020 KPSS Eğitim Bilimleri Hzzl Seri Hem Konu Hem Soru) Hedef 2020 - Eğitim Bilimleri - Hzzh Seri Hem Konu Hem Soru Bankası, (Eda Bayrak İz Burakanlar Hacı Bektaş Veli) Hacı Bektaş Veli - İz Burakanlar, (Eda Bayrak İz Burakanlar Akşemseddin) Akşemseddin - İz Brrakanlar, Dünya Klasikleri - Kamelyalı Kadın - Alexandre Dumas, Dünya Klasikleri Kumarbaz, Bebeğiniz Mişıl Mışıl Uyusun Janet Krone Kennedy vb.

\section{Anlatım bozuklukları}


Ürünler hakkında bilgi verilen "beyaz eşya, bilgisayar, elektrikli ev aletleri" gibi kategori sayfalarıyla "sık sorulan sorular" sayfasındaki metinlerden anlatım bozukluğu tespit edilen ifadeler, düzeltme önerileriyle aşağıda sıralanmıştır:

Her bireyin, her ofisin ve her evin temel ihtiyaçlarndan biri olan bilgisayarlar, günümüzde sürekli kendini getiştiren [geliştirilen] ve en çok seçeneği sunan [bulunan] elektronik aletler arasındadır.

Kalabalık ve bol [çok] misafirli ailelerde butaş̧t tek tek ve elde [bulaşık] yıkamak oldukça zahmetli ve suyun aşırı tüketimi açısından oldukça kötüdür [masraflıdır.]

Diğer tüm beyaz eşyalarda [da] dikkat edilmesi gerekli olduğu gibi [gereken] enerji tasarrufu konusu son derece önemlidir.

Kiş̧i sayısmm fazla olduğ kalabalık aileler[in] için ise çok kilogram kapasiteli büyük bir makineye ihtiyacı vardır. Çamaşırın kurutacak yeri olmayan kişiler ise kurutma makinesi de içerisinde olan çamaşır makinesi tercih edip her [hem] yerden tasarruf eder hem de iki kişi-[işi] tek bir ürünler halletmiş olur.

Güzel yemeklerin piştiği, içinden iştah açan kokuların sızdiğı firınların mutfağımızın baş taçlarıdır.

Bilgisayar satın alırken bütçenizi belirledikten sonra ne tür donanıma bağłt [sahip] bir bilgisayar alacağınızı belirlemeniz gerekmektedir. [Bilgisayar alırken önce bütçenizi sonra donanım ihtiyacınızı belirleyiniz.]

...herhangi [bir] parçasına bir şey olması durumunda hemen o parçayı yenileyebilir [değiştirebilir] ve yeni gibi bir bilgisayara sahip olabilirsiniz.

İkinci en önemli donanım ise bellektir. ("En" olan bir tanedir.)

Evimizin, işyerimizin vazgeçilmez elektronik aletlerinden olan elektronik ev aletleri en önemli yardımcılarmız[dir.] olarak yer alıyor.

Evimizin her köşesine[i] dipten uea kadar [köşe bucak] temizleyen süpürgeler[in] torbah, torbasız, su filtreli olarak öne çıkłyor [çeşitleri vardır.]

Yemeğinizi hazırladıktan sonra pişirme aşamasında kullanacağınız mini ve midi firmlar ile lezzetli yemekleri pratik ve hızlı bir biçimde hazırlamanıza [pişirmenize] yardımcı oluyor.

Bütçe dostu alternatifleri [fiyatları] ile oldukça [fazla] seçeneği içinde barmdıran elektrikli ev aletleri [bulunan bu] kategorisinden sizde [siz de] evinize uygun bir elektrikli ev aleti satın alabilirsiniz.

İstek[lerinize] ve ihtiyaçlarmıza yönelik ürün geliştiren ve tasarlayan cep telefonu ve göre tasarlanan cep telefonu aksesuar[larıyla] markaları ile telefonunuzu çizilme ve darbelere karşı koruyabildiğiniz gibi aksesuarlam ile kişiselleştirebilir ve hayatımızı kolaylaştırabilirsiniz.

Sürekli değişen iş [hayatı] ve günlük hayat koşullarma yönelik [uygun] en güncel telefon modelleri arasından ihtiyacmıza ve bütçenize yönelik [uygun] cep telefonlarından [birini] size uygun olant satın alarak kullanabilirsiniz. 
...basit ve uygun bir model sizler [benim] için yeterli olur mu ve [mi,] bütçem ne kadar gibi sorularn cevapları sizlere uygun modeli bulma da [bulmada] yardımcı olacaktır.

Gelişen teknoloji ile televizyonlartnda [televizyonlarn da] özellikleri giderek artıyor ve her ihtiyaca hizmet etmeye ȩahş̧yor. [l karşıllyor.]

Günümüzde artık televizyonlarında [televizyonlarm da] birbirinden farklı özelliği [özellikleri] ve alternatifleri var. Curved TV, smart TV, LED TV, büyük ekrantar, küçük ekrantar, sensi TV, oled TV, $4 K$ TV [gibi] seçenekleri önümüze çıkıyor. [var.]

... markalarından bütçenize uygun olanı seçip, bütȩenize göre markayı da belirledikten sonra satın alma işlemini gerçekleştirebilirsiniz. [alabilirsiniz.]

LED, LED TV'ler diğer televizyonlar[a] ve LCD televizyonlara göre daha ince tasarma sahiptirler. Ayrıca daha geç ısınma[ları] ve daha az enerji hareıyor oluşları ile öne çıkıyorlar. [harcamalarıyla

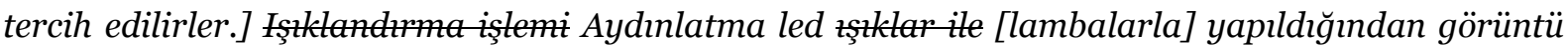
kaliteleri de LCD televizyonlara göre oldukça iyidir.

LCD [TV'ler], Led TV'lerin aksine daha fazla enerji tüketme[kte] ve daha çabuk ısinmaktadirłar. Işıklandırmaları [aydınlatmaları] floresan ile yapıldığından dolayı görüntü kalitesi de LED TV'ler kadar iyi değildir.

Oled TV['lerin], ekranları oldukça ince olduğundan dolayı bu özellik Oled TV'lerin [bunlar] az enerji tüketmesine tüketir ve oldukça hafif[tir.] olmasma neden olur.

Bebeğinizle geçirdiğiniz vakti daha emniyetli hale [hâle] getirecek olan bebek telsizler[ini], bebek güvenlik kameraların da unutmamak gerekir. Bunların dışında en önemli strada yer alan bebek arabaları, ana kucakları, kendiliğinden elektrikli sallanan [kendiliğinden sallanan elektrikli beşikleri], mama sandalyelerini unumamak gerekir. [unutulmamalıdır.]

Alternatif seçeneğinin [Seçeneğin] fazla olması en uygun ürünü bulmanız[da] için çok yardımcı olacaktır.

Yüzlerce seçeneği uygun fiyata sunan bu kategori de [kategoride] çocuğunuzun ihtiyacina yönelik olan her ürünü bulabilirsiniz.

Kozmetik[ler] ̈̈rünler hem kendinizi [kendimizi] daha bakıml hissetmek hem de daha çekici olmak için kullandığımız ürünlerdir. Bunlar [arasında] ilk sırada makyaj ürünleri, cilt bakım[ı] ürünleri, saç bakım[1] ürünleri, parfümler ve deodorantlardır. [bulunur.]

Kozmetik ürünler [kategorisinde] stralamasında ilk strada karşımıza çıkan makyaj ürünlerinde yüz makyajı için fondöten, allık, pudra, kapatıcı, makyaj bazı, aydınlatıcı [;] göz makyajı için maskara, eyeliner, göz kalemi, göz farı, takma kirpikler [;] dudak makyajı için stik ruj, dudak parlatıcısı, dudak kalemleri, likit rujlar kullantlır. [bulunur.] Makyaj aksesuarn deyinee de [olarak kullanlan] organizerlar, [düzenleyiciler,] makyaj firçaları, kirpik kıvırıcılar, aynalar, makyaj çantaları, makyaj aplikatörleri [de] bu kategoride yer alır. 
...güzel ve bakıml görünmek insanın hem kendini iyi hissetmesini sağlar hem de diğer insanlar[da] aȩısından iyi bir izlenim bırakılmasına yardımcı olur.

"A101'E ÜYE OL" formu[nu] doldurarak kolayca üye olabilirsiniz.

Ahconın adreste bulunmaması durumunda, gelen kargoya ait bilgilerin yer bulunduğu ve kargosunu 3 gün içinde şubeden alabileceğini belirten “Adresten Teslim İhbar Notu'” brrakulır.

[Ücret iadesi] Ürün iade ya da iptal işlemi onaylandıktan sonrastnda üeret iadesi, ahşveriş esnasında kullandığımı banka-kredi kartına yapılmaktadır.

... kampanya koşulları değiş̧irilebilir ya da kampanya sonlandırılabilir. [bitirilebilir.]

Ayruca hediye çekinin son kullanım süresini [tarihini] kontrol etmeniz [etmelisiniz] ve çek kodunu doğru girdiğinizden emin olmalısınız.

"Kurumsal" ve "Sözleşmeler" sekmesinde bulunan mevzuat, alıntılanarak uyarlandığı için bunlardaki yanlışlıklar çalışmanın çerçevesi dışında tutulmuştur.

\section{Yazım yanlışları}

Ağ sayfasındaki yazım yanlışları şöyle sıralanabilir:

a) Büyük ve küçük harflerin imlasıyla ilgili yanlışlar: Ürün adları, bunların nitelikleri ve nicelikleri yazılırken "ve, için, ile" gibi edatlar dâhil neredeyse bütün kelimelerin ilk harfleri büyük harfle yazılmıştır. Bazı örneklerde ise tutarsızlıklar vardır: Şakanın Da Bir Sınırı Var!, Kaktüsler De Çiçek Açar, Bunları Biliyor Musunuz? Ben Ne Giydiğimi Biliyor Muyum?, Pofi İle Tam Zamanında, Ayıcık Mavi İle İyi Geceler Masallar Seti; Veri Güvenliğiniz İçin Alnan Tedbirler ve Benimsenen Prensipler, Araplar İçin Türkçe Konuşma Kılavuzu, Çocuklar İçin Sudoku.

Tamamı büyük harflerle yazılan ifadelerde geçen "ve, veya, ile, da, de, ki" bağlaçlarıyla soru eki büyük harflerle yazılması gerekirken küçük harflerle yazılmış: ...GİZLILIKK ve KISŞISEL VERILLERIN KORUNMASI..., TANIM ve KISALTMALAR, ...KULLANIM AMACI ve VERI İLGILISINININ HAKLARI.

Büyük harfle başlatılması gerekmediği hâlde büyük harfle yazılan kelimelere rastlandığı gibi normalde büyük harfle başlaması gereken kelimelerin küçük harflerle yazıldığı örnekler vardır: Kişisel Verilerin Korunması Kanunu kapsaminda yapılan Aydınlatma Metni'ni okudum, onaylyorum; Hediye Çeki/İndirim Kodu'nun kullamıldiğı uyarısı alıyorum, ne yapmalıyım?, Kiralık Yeriniz mi var?, Boyama Kitabl/korsanlar Kral, Guliver'İn Gezileri

"ürün stoklarımızda tükenmiştir!, ürün gelince haber ver" gibi örneklerde ise cümle başında büyük harf kullanılmamış ve noktalama yanlışı da yapılmıştır.

Kişisel verilerin korunması hakkında bilgilendirme yapılan sayfadaki kanun maddelerinin ve büyük harflerin imlasında tutarsızlıklar vardır: AMAÇ VE KAPSAM, TANIM ve KISALTMALAR, Veri Sorumlusu, Verilerin Korunmasından sorumlu temsilci, Kişisel verilerin işlenmesine ilişkin uyulacak ilkeler, Kişisel Verilerin Güncel Tutulması 
b) Birleşik kelimelerin imlasıyla ilgili yanlışlar: Ayrı yazılması gerektiği hâlde bitişik yazılanlardan şu örnekler seçilmiştir: Kuruyemiş [Kuru yemiş], Anakucağı [Ana kucağı], ® Ayçekirdeği [® Ay çekirdeği], Çörekotu [Çörek otu], Çörekotlu [Çörek otlu], Antepfistıkl [Antep fistıklı], Dizaltı İnce Çorap [Diz altı ince çorap], Kullanat [Kullan at], haftaiçi saat 15:30 [hafta içi saat 15.30], Anasayfada... [Ana sayfada...], Yurtiçinde... [Yurt içinde...], yurtdışına [yurt dışına], Önlisans [ön lisans] işyerimizin [iş yerimizin]; ... ofislerimizin demir başı [ofislerimizin demirbaşı], ... masa üstü [masaüstü] bilgisayar (Aynı cümlede bitişik yazılmış şekli de var.),

Aşağıdaki örneklerde bağlaç olduğu için ayrı yazılması gereken "da, de" bitişik, bulunma hâli eki "-DA" ayrı; bitişik yazılması gereken "ki" eki ise ayrı yazılmıştır:

Günümüzde artık televizyonlarında..., bulunan televizyonlarda kendi içinde..., ... sizde evinize uygun...; Yüzlerce seçeneği uygun fiyata sunan bu kategori de çocuğunuzun..., uygun modeli bulma da yardımcl; ...evlerimizde ki en büyük

c) Ürün/ambalaj üzerindeki markaların, ibarelerin, kısaltmaların ve diğer bilgilerin ağ sayfasına yanlış veya eksik yazımından kaynaklanan yanlışlar: (ABC) Abc, (ALO) Alo, (MEB) Meb, (YKS - AYT) Yks -

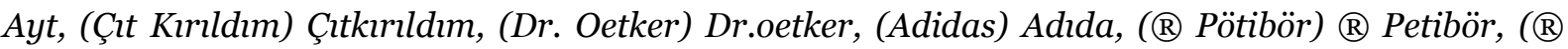
Üzümlü Frndıkl) - @ Çikolata Üzüm-Frndık, (® Big Brownie) @ Big Brownie'li Tahıllı Bar, (® mentol) ${ }^{\circledR}$ Menthol, (İlköğretim Atasözleri ve Deyimler Sözlüğü) Atasözleri Ve Deyimler, (Yazım (İmla) Kılavuzu) Yazım ve İmla Klavuzu, (Afacanlar İş Başında, (Lisa Tablomu Çaldılar Küçük Leo DaVinci)) Lisa Tablomu Çaldı Küçük Leo DaVinci, (Haddini Bilmek!) Haddini Bil!, (İlk Bilgilerim Sayı Kartları) Sayı Bak Öğren Kartları - İlk Bilgilerim, (İlk Bilgilerim Meyve Kartları) Meyve Bak Öğren Kartları - İlk Bilgilerim o-3 yaş, (İlk Bilgilerim Sebze Kartları) Sebze Bak Öğren Kartları - İlk Bilgilerim o-3 yaş, (İlk Bilgilerim Harf Kartları) Harf Bak Öğren Kartları - İlk Bilgilerim, (İlk Bilgilerim Hayvan Kartları) İlk Bilgilerim - Hayvan Bak Öğren Kartlarn

ç) Eksik/yanlış yazılanlar: Gardrop Dü[z]enleyici, Böğ[ü]rtlenli, Sutlu [sütlü], ® Kă̆ıt [Kâğıt] Helva, ( Kağıt [Kâğıt] Mendil, Yeni Nesil Amonyak[lı], @ Yedek Yuvarlık [Yuvarlak] Mop, Extra [Ekstra] Güçlü Çöp Torbası, Uzay Gemizi [Gemisi], Kaymaz Taban Saça[klı] Hah, Kadın Ayak[kabısı], Deniz Yatağ[1], Omuz Askılı Çant[a], ® Elektrikli Bis[i]klet, ® Ahşap Stanth [ß̧tandlı] Sosluk, ® Bebek Maması Ekbesn Balirmk [Ek besin, sütlü, ballı, irmikli], Elektrikli Bis[i]klet, ${ }^{\circledR}$ Parfüm 10oml \& Deodoran[t], 5 Çekme[ce]li Organizer, @ Güneşlikli Bebek Şişme Havuz [® Güneşlikli Şişirme Bebek Havuzu], ® Far Firçası R[e]nkli, Yks -Ayt Türk Dili Ve Edebiyatı Soru Ba[nkası], 9. Sinıf Türk Dili Ve Edebiyatı Soru Ban[kası], Kalemt[ı]raş Seti,

Kampanyalar belirlenen süreler dahilinde [dâhilinde] yapılamaktadır [yapılmaktadır]. ...KISSiSiSEL VERILER[İ]N KORUNMASI... KDV dahil [dâhil], Bunu[n] yanı sira..., ...hala da... [hâlâ da...], Bu yüzden piyasa[da] çok çeşitli bilgisayar...

d) Farklı imlalarla yazılanlar: Aynı ifadelerden değişik sayfalarda farklı imlalarla yazılanlardan seçilen örnekler şunlardır: @ Bulaşık Makinası - @ Bulaşık Makinesi, Gardırop - Gardrop, Spray - Sprey, Email - E-mail, Eposta - E-posta, Saklama Kabı 3 Lü, 4 Lü Tornavida Seti, Tornavida 3 lü set, 3'lü Ankastre Set,

\section{\& İşareti}


Kelime olmadığı için İngilizce sözlük maddeleri arasında bulunmayan \& işaretine genellikle sözlüklerin "işaretler ve semboller" kısmında yer verilir. Bağlama edatı olarak "ve, ile, beraber" işlevlerinde kullanılır. "İngilizcede, bu işaret, ikiden fazla unsuru birbirine bağlama sırasında, genellikle, unsurlar virgülle ayrılmakta veya boşluk bırakılarak son iki unsur arasına getirilmekte iken Türkçe ilânlarda kaç unsur belirtilmek isteniyorsa hepsinin de arasına birer adet \& işareti getirilmesi daha yararlı, daha pekiştirici, bütünleştirici (kütleleştirici) sayllmaktadır" (Ersoylu, 1993b: 184). "Ve" ya da "ile" bağlacı yerine yahut kısa çizgi veya virgül işareti yerine rastgele, tutarsız biçimde Türkçede bulunmayan bu işaretin yazılması doğru değildir.

Giyim ve Aksesuar, Oto Bakım[l] ve Aksesuar ifadelerinde "ve" bağlacı kullanılırken şu örneklerde bağlaç veya (kısa çizgi, virgül gibi) noktalama işaretleri yerine \& işareti tercih edilmiştir: Mağaza \& Online, Ev \& Yaşam, Anne \& Bebek, Kozmetik \& Kişisel Bakım, Kitap \& Kirtasiye, cips \& çerez, Süt Ürünleri \& Kahvalthllk, Telefon \& Aksesuar, Televizyon \& Ses Sistemi, Spor \& Hobi Ürünleri, Isttma \& Soğutma ürünleri, Çalışan \& Müş̧teri; ${ }^{\circ}$ Banyo\&Mutfak Krem Temizleyici, ${ }^{\circledR}$ Mısır \& Pirinç Patlağı,

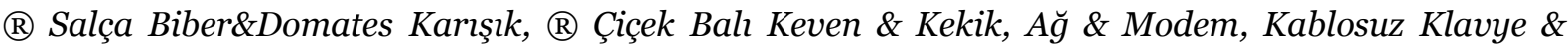
Mouse Set, ${ }^{\circledR}$ Kulak \& Burun Krl Kesme Makinesi, Şarj Cihazı \& Kablo, ${ }^{\circledR}$ Kedi Mama \& Su Kabı, @ Sıvı Sabun Yulaf \& Buğday, Yüz Temizleme Sütü Kuru \& Hassas Ciltler, Normal \& Karma Ciltler için,

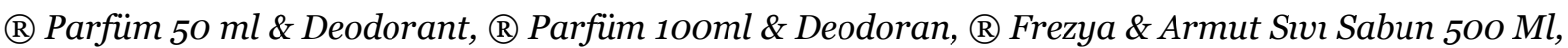
(®) Bronze Far\&Allk Paleti, ® Saç Kremi Onarıcı\&koruyucu, ® Besleyici\&Hacim Veren Maskara, Din \& Mitoloji, Ana \& İki Şehrin Hikayesi - Dionis Yayınları. Bu arada büyük harflerin ve küçük harflerin imlasıyla ilgili hususlar gözetilmediği gibi çok sayıda tamlama ve sıralama yanlışı da yapılmıştır. Sanki tek kelimeymiş gibi aralarında boşluk bırakılmadan yazılanlar da dikkat çekmektedir. Oto \& Bahçe \& Yapı, Deterjan \& Temizlik \& Kağıt, Un \& Bakliyat \& Baharat örneklerinde ise üçer kelimelik bu gruplar arasına da ayırıcı noktalama işareti yerine \& işareti konması da Türkün dil mantığıyla uyuşmaz.

\section{$+($ Artı) İșareti}

Türkçede "ayrıca, ilaveten, buna ek olarak, dahası, üstelik, bundan başka, fazlası, bunun dışında; ve" gibi ifadelerin yerine "fazla, daha çok, daha" anlamındaki plus sözünün artı şeklinde çevrilerek sanki aritmetik işlem yapıyormuş gibi kullanılmasındaki sıklık ne yazık ki her geçen gün artmaktadır. "İngiliz dilinde 'bundan başka, üstelik, ayrıca' gibi karşılıklarla zarf olarak, ancak, 1950'den itibaren yazılan metinlerde görülmeye başlanan 'plus: artı' kelimesinin bir bağlama edatı işlevi 'and' (ve) ile kullanılması çok daha yeni olup (1968'den bu yana) genel olarak da konuşma dili İngilizcesindedir. Önemli, ciddi yazılarda 've' işlevi ile kullanılması ise olumsuz tepkileri çekmektedir" (Ersoylu, 1993a: 9). Bu işaretin matematikte toplama, elektrikte pozitif kutup için kullanıldığı hatırlanırsa karışıklı̆̆ın önemi daha iyi anlaşlacaktır. Şu örneklerde "yanında, ile, ve, ek olarak, ilaveli" gibi kelimeler veya virgül işareti yerine + işareti konmuştur: $\AA^{\circledR}$ Elektro Isıtıcı +1o Mat Tablet, $₫$ Garnitür+Mayonez Seti 570/27o G, @ Mouse+Mouse Pad Hediye, Trraş Makinesi + Traş̧ Bıçağı, Sikılaştırıcı Krem $50+50$ ml, 5+2'li Kullan At Tiraş Bıçağı, ® Tiraş Makinesi + 3'Lü Tiraş Bıçağı Seti, ® Parfüm 50 ml+Deodorant, ${ }^{\circledR}$ Parf 10oml+deo15o Ml, ${ }^{\circledR}$ For Men Intense Edt $75 \mathrm{ml}+$ Deodorant Stick $75 \mathrm{gr}$ Erkek, ® Güç ve Hacim Veren Saç Serumu + Saç Maskesi, ® Renk Canlandırıcı Saç Serumu + Saç Maskesi, Diş Mac.kil Ext Beyaz 75 Ml+diş Firçası, ${ }^{\circledR}$ 3D Silgili + Min Versatil Set, Lisansh 3 Silgi + Kalemtraş Set, Kalem Set (Kalem+Silgi+Kalemtraş). 365 Zeka Geliştirici Aktivite Seti 8 Kitap, + 4 yaş örneğinde ise "4 yaş ve üzeri/4+" yerine "+4" yazılmıştır.

\section{Noktalama yanlışları}


Noktalama işaretlerinin kullanılmasıyla ilgili en önemli yanlışlık ve tutarsızlık, virgül işareti veya ayırma işareti (-) konması gereken yerlerde bu işaretlerin yazılmamasından ve husustaki tutarsızlıklardan kaynaklanmaktadır. Ürünün nitelikleri gelişigüzel sıralanırken bunlar arasına ayırıcı bir işaret konmadığı gibi ürünün adedini, kodunu, ağırlığını, hacmini gösteren sayıların da bir işaretle ayrılmaması dikkat çekicidir. Atasoy (2018: 332), ikilemelerle karışması istenmeyen ikili öbekler arasına kısa çizgi işareti konularak bunlar arasında ilgi kurulduğunu belirtir. Yazım Kılavuzu'nda, peş peşe sıralanan sıfatları/kelimeleri ayırmak için kısa çizginin de kullanılabileceğine dair bilgi yoktur:

( Sultani Bisküvi Üzümlü Kepekli, @ Big Brownie'li Tahıllh Bar, ${ }^{\circledR}$ Üzümlü Findıkh - ${ }^{\circledR}$ Çikolata Üzüm-Findık, @ Firn Ocak Temizleyici, @ Mutfak-Banyo Krem Temizleyici - Limon Aromalı, @

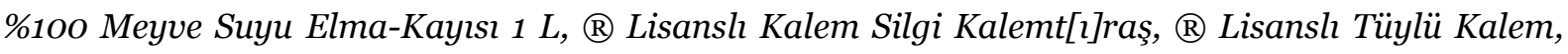
Silgi, Kalemt [1]raş Seti, ® Garnitür+Mayonez Seti 570/270 G, ® Desenli-Çizgili Erkek Boxer - Siyah M, ® Saç Boyası Koyu Kahve 3-o, A4 120 Yaprak 3+1 Seperatörlü Kapak Defter vd.

Yazar, kitap ve yayınevi adlarını ayırmak için bunların arasına bazılarında kısa çizgi, bazılarında eğik çizgi konmuş bazılarında ise herhangi bir noktalama işareti konmamıştır. Üstelik yazar, eser ve yayınevi adlarının sıralanmasında da birlik yoktur: Meltem Soyugüzel Kişisel Gelişim Seti - 3 Kitap, Aforizmalar - Franz Kafka - Olimpos Yayınlar, Hayat Güzel De 'De"leri Var İşte - Cihad Kök, Bay Sıska Bacak - Çocuk Klasikleri - Ciltli, Bay Sıska Bacak - Resimli Dünya Klasikleri, Siyah İnci - Çocuk Klasikleri - Ciltli, Büyük Umutlar - Çocuk Klasikleri - Ciltli, Gulliver'in Gezileri - Çocuk Klasikleri Ciltli, Orman Kitabr - Çocuk Klasikleri - Ciltli, Robin Hood - Çocuk Klasikleri - Ciltli, Robinson Crusoe / Dünya Çocuk Klasikleri, Tuti - Sihirli Kelimeler, Tuti - Saklanan Hayaller, 5 Süper Set; Sayzlar Renkler - Şekiller - İlişki Kurma - Zıt Kavramlar vd.

Kitabın kapağındaki (İngilizce-Türkçe Türkçe-İngilizce Sözlük) adı ă̆ sayfasına yazılırken İngilizce Türkçe Sözlük şeklinde hem eksik yazılmış hem de dil adları arasına konması gereken kısa çizgi işareti yazılmamıştır.

Atasoy (2018: 332), kısa çizgi işaretinden önce ve sonra boşluk bırakılmasının doğru olmadığını da belirtir.

Siralama gösteren sayılardan veya harflerden sonra genellikle nokta ya da yay ayracın kapama şekli yerine iki noktalama işaretinin kullanılması yanlıştır: 1-), 2-), 3-); $a$-), $b$-) gibi.

"Siparişimi iptal - iade ettim." örneğinde eğik çizgi yerine kısa çizgi işareti yanlış kullanılmıştır.

Sayıların kesirli kısımlarını ayırmak için virgül yerine nokta konması da yanlıştır: $2.5 \mathrm{KG}, 2.6 \mathrm{~kg}$ vd.

Aynı pakette birden fazla ürün bulunması durumunda bunun $3 \times 36 \mathrm{~g}$, örneğindeki gibi gösterilmesi yaygınlık kazanmışken araya çarp işareti yerine * işareti konması da uygun değildir: $5^{*} 2 O G$.

Diğer noktalama yanlışları: haftaiçi saat 15:30 [hafta içi saat 15.30]; T.C [T.C.]; 2015-2016-20172018 yillarinda [2015-2018 ylllarl arasında]; YENİ MAĞAZACILIK A.Ş. (“A1O1”)'ye ... [YENI MAĞAZACILIK AŞ “A1O1” ...]

\section{Kısaltma yanlışları ve tutarsızlıkları}


Ağ sayfasında ürün adları gelişigüzel kısaltıldı̆̆ı gibi bu kısaltmalar arasında da birlik yoktur. Özellikle kilogram, gram, litre, mililitre (kg, g, l, ml) gibi sık kullanılan kısaltmaların tutarsızlı̆̆ı dikkat çekmektedir: $2.5 \mathrm{KG}, 2.6 \mathrm{~kg} ; 116 \mathrm{G}, 107 \mathrm{G}, 5^{*} 20 \mathrm{G}, 3 \times 36 \mathrm{~g} ; 20 \mathrm{Lt}, 1 \mathrm{~L} ; 1500 \mathrm{Ml}, 250 \times 2 \mathrm{Ml}, 1350 \mathrm{ml}, 650$ $\mathrm{ml} ; 750 \mathrm{Cc}, 600 \mathrm{cc}$.

Ürün üzerinde doğru yazılmış kısaltmaların ağ sayfasında farklı bir imlayla yazıldığı tutarsız örnekler de vardır: (® 32 GB USB Bellek), ® 16 Gb Usb Bellek; Eau De Parfume (EDP) Edp, Eau De Toilette (EDT), ® Edt Parfüm; Kpss, (® TYT AYT) - Tyt-ayt, Meb; Led TV, LED TV, Smart Tv, Smart LED $T V$, oled, OLED.

Şu örneklerdeki kısaltmalarda ise herhangi bir ölçüt gözetilmediği gibi sıralamaya da dikkat edilmemiştir: ® Cips Patates Yoğurt Mevs. Yeş., ® Zencefil Sert Şeker Bitk. 5 G, ® Çik. baton Karamelli, ${ }^{\circledR}$ Çik.yer Fistıkh, $₫$ Bisküvi Mars.hindistan Cevizli, ${ }^{\circledR}$ Kraker Çubuk Bah., ( ${ }^{\circledR}$ KOLA) ( Jelly Kola Yum.şeker, (® AYICIK) - ® Jelly Yum.şeker 28G/3o Ayıcık, Kek Marsm. Kakaolu 8x23

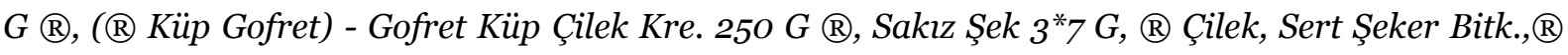
Burger Kre. Bisküvi, Çikolata Böğürtlen Aro.dol $5^{*} 25$ G ${ }^{\circledR}$, ${ }^{\circledR}$ Draje Çik. Kaplı A.fistıkl, ${ }^{\circledR}$ Cho-co Corn Bar Çikolata Hin. Cevizli, ® Bar Çik.hin.cev.marshmallowlu, Oda Kumaş Spr.bahar Tazeliği $400 \mathrm{Ml}$ ®, ® Bulaşık Mak. Kapsülü, @ Yumuşatıcı Konsantre Yab.orkide\&yasemin, @ Gül Yumuşatıcı Kon Karma, ® Premıum Tnk Türk Kahvesi, Nar Aromalı Antep Fis.sucuk, Toz Tath Sakızh Muhallebi 15og Dr.oet., ® Hayv. Kost.kahve. Bebek [Hayvan Kostümlü Kahverengi Bebek],

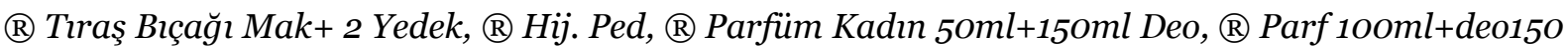
Ml, ® Saç Kremi Saç Dökülm. Karşı, ( $($ Kil ile Extra Beyazlık) - Diş Mac.kil Ext Beyaz 75 Ml+diş Frrçası, Gün Krem Derm Exp. Age Perfec $50 \mathrm{Ml} \AA$

Ürün adlarının ve üründeki ifadelerin ağ sayfasına rastgele yazıldığ (Kolaydan Zora Soru Bankası Din Kültürü ve Ahlak Bilgisi TYT AYT 3256 Soru)- Tyt-ayt Din Kül.ve Ahl.bil Kol.zor Sor, (Dünya Çocuk Klasikleri Billur Köşk Masalları) - Dünya Çoc Klasik Billur Köşk Masalları, (Dünya Çocuk Klasikleri Binbir Gece Masalları) - Dünya Çoc Klasik Binbir Gece Masalları, Kişisel Geliş. Sira Dışı Düşüncenin Gücü, Kiş. Geliş. Başarıya Götüren Anne-baba, Tyt-ayt Din Kül.ve Ahlak Bil.konu Anl, Tyt-ayt Din Kül.ve Ahlak Bil.çă̆.soru Ba; (® Yoğurt ve Mevsim Yeşillikli) - ${ }^{\circledR}$ Patates Yoğurt Mevs. Yeş. 107 G.

\section{Sonuç}

Türkçenin güncel ve önemli sorunlarından biri de sezgiye dayalı anlaşmayla yetinme anlayışıdır. Bunun doğal bir neticesi olarak dile gereken özen gösterilmeyince her geçen gün dil yanlışlarına yenileri ekleniyor. Bunlar da her türlü kitle iletişim aracıyla hızla yayllıyor. Bu durum, Türkçenin geleceği adına bizi kaygılandırmaktadır.

Ürün çeşitliliği, daha uygun fiyat, kolaylık, zamandan tasarruf, teknolojik imkânlar gibi çeşitli etkenlerle internetten alışveriş yapanların sayısı gittikçe artmaktadır. Dolayısıyla e-ticaret amacıyla tasarlanan ă̆ sayfalarındaki dil yanlışları ve dilin özensiz kullanımı hem bu web sitelerini örnek alarak tasarlanan yenilerini hem de kullanıcıları olumsuz etkilemekte, yanlışların yayılmasına sebep olmaktadır.

A101 örneğiyle sınırlı bu çalışmada tespit edilen olumsuzlukların çoğu tamlama yanlışları, yazım ve noktalama yanlışlıkları, anlatım bozuklukları ve tutarsızlıklardan kaynaklanmaktadır: A $\breve{g}$ sayfasında 
arama yapıldığında daha fazla sonuç ve ürün görüntülenebilsin diye tamlama değil de kelime esas alınarak oluşturulan algoritmalar, bazı örneklerde tamlama yanlışlarına sebep olmaktadır. İsim tamlamalarındaki en önemli yanlış, iyelik eki eksikliğinden kaynaklanmaktadır. Sıfat tamlamalarındaki yanlışlıkların çoğu, tamlanan isme ait niteleyenlerin ve belirtilenlerin yanlış sıralanmasıyla bağlantılıdır. Değişik tasarımlarla/kompozisyonlarla ürün ambalajında yer alan (ürünün markası, serisi, niteliği, içeriği, bedeni, rengi, ebadı, ölçüsü gibi) bilgiler, sıra gözetilmeden ve sıralananlar arasına ayırıcı noktalama işareti konmadan (hatta birbirleriyle tutarsız biçimde) a ğ sayfasına aktarılmıştır.

Çok sayıda kişiye/müşteriye hitap eden bunun gibi ă̆ sayfalarında iletişimin en önemli unsuru olan dile gereken özen gösterilmelidir. Ağ sayfalarını yukarıda bahsedilen yanlışlıklardan arındırmak çok da zor olmasa gerektir. Sabit bilgilendirmeler ve kategori başlıkları bir uzmandan yardım alınarak bir defada kalıcı olarak düzeltilebilir. Ürün bilgileri, doğru yazımla ve doğru sırayla veri tabanına girilebilir. Hatta üreticiler, ürün görsellerini ve ürüne ait bilgileri kendi ağ sayfalarından çekilebilecek uygulamalar geliştirebilirler.

\section{Kisaltmalar}

(®) : Tescilli marka işareti, marka adı yerine kullanılmıştır.

vb. : Ve benzerleri

vdm. :Ve diğer markalar

TDK : Türk Dil Kurumu

\section{Kaynakça}

Akşehirli, S. (2015). Türkçede Sıfat Dizilim Sınırlılıkları. 29 Ulusal Dilbilim Kurultayı, Kocaeli, 21-22 Mayis 2015.

Atasoy, F. O. (2018). Türkçede Noktalama Sorunlar - Çözümler - Teklifler. Ankara: TDK: 1274.

Ergin, M. (1982). Türk Dil Bilgisi, İstanbul: Boğaziçi.

Ersoylu, H. (1993a). Çağdaş Türkiye Türkçesinin Problemleri: 1 + (Artı), Türk Dili, S 493, Ankara, s. 710.

Ersoylu, H. (1993b). Çağdaş Türkiye Türkçesinin Problemleri: 3 \& (And Sign), Türk Dili, S 500, Ankara, s. 181-186.

Ersoylu, H. (2009). Türkiye Türkçesinin Çağdaş Sorunları Üzerine İncelemeler. İstanbul: Ötüken.

Karaağaç, G. (2016). Türkçenin Dil Bilgisi, Ankara: Akçağ.

Görgülü, G. (2008). Pazarlamada Türkçe Yanlışları. Erişim adresi (6 Mart 2020) https://www.dunya.com/kose-yazisi/pazarlamada-turkce-yanlislari/1773

Özezen, M. Y. (2006). Türkiye Türkçesinde Sıfat İşlevli Birimler: Dizilim, Nitelik, Nicelik, Birliktelik. Journal of Turkish Studies (Türklük Bilimi Araşttrmalarl)- Festschrift of Orhan Okay II (Orhan Okay Armağanı II) vol 30, 2006, s. 381-405.

Özünlü, Ü. (1978). Türkçede Sıfatların Niteleme Öbeği İçindeki Sıraları. Genel Dilbilim, Şubat, 1978, S.43-47.

TDK (2018). Yazım Kılavuzu. TDK.

Tokyürek, H., Pekacar, Ç. (2014) Eski Türkçeden Günümüze Eksiz Ad Tamlaması Meselesi. Dil Araştırmalart, S 15, Güz, s. 9-38. 